\title{
The role of institutions in the production of space for tourism: National Forest Parks in
} China

\author{
A/Professor Fen Luo ${ }^{a, b}{ }^{*}$, Dr Brent D. Moyle ${ }^{\mathrm{b}}$, Professor Jigang $\mathrm{Bao}^{\mathrm{c}}$ and Professor Yongde \\ Zhong ${ }^{\mathrm{a}}$
}

${ }^{a}$ College of Tourism, Central South University of Forestry \& Technology, China, 410004, eno.498, Shaoshan South Road, Changsha,Hunan:luofen79@gmail.com; adely@csuft.edu.cn, Phone: +86 18008421922; +61451997903.

${ }^{b}$ Griffith Institute for Tourism, Griffith University, Business 2 Building (G27) Room 3.06, 58

Parklands Drive, Southport Qld 4222 Australia, 4215; e-mail: f.luo@griffith.edu.au;

b.moyle@griffith.edu.au

${ }^{c}$ Centre for Tourism and Planning Research, No. 135, Xingang Xi Road, Guangzhou, Yat-sen University, China, 512007; e-mail: eesbjg@mail.sysu.edu.cn.

* Corresponding author

\begin{abstract}
Nature-based tourism is a global phenomenon, with traditional forms of use of natural areas, such as wood harvesting and agriculture, paving the way for ecotourism. However, there has been limited exploration of the role of institutions in driving this transition. Consequently, this paper sought to explore the role of institutions in producing space for tourism within National Forest Parks (NFPs) in China. To achieve this objective 68 national-level policy documents from 1949 to 2014 were collected and analyzed. Findings demonstrate a transformation in the role of NFPs, orchestrated by the state, capital and society for tourism. In particular, NFPs, as an ideological space in national development, were not only an outcome of economic, social, political, and ecological processes, but also balanced the power between the state, capital and society. Institutional changes mirrored the dynamic relationship between the state, capital and society in China. Future research should focus on the role of institutions in producing space for tourism for and within parks at the local level, especially in developing contexts.
\end{abstract}

Keywords: Tourism; Conservation; Spatiality; Institution; National Forest Parks; China 
The role of institutions in the production of space for tourism: National Forest Parks in China 


\title{
The role of institutions in the production of space for tourism: National Forest Parks in China
}

\begin{abstract}
Nature-based tourism is a global phenomenon, with traditional forms of use of natural areas, such as wood harvesting and agriculture, paving the way for ecotourism. However, there has been limited exploration of the role of institutions in driving this transition. Consequently, this paper sought to explore the role of institutions in producing space for tourism within National Forest Parks (NFPs) in China. To achieve this objective 68 national-level policy documents from 1949 to 2014 were collected and analyzed. Findings demonstrate a transformation in the role of NFPs, orchestrated by the state, capital and society for tourism. In particular, NFPs, as an ideological space in national development, were jointly shaped by the state, capital and society to meet economic, social, political, and ecological requirements at the national level. A three phased conceptual triad is presented to illustrate how space was produced, transitioning from forestry, to ecological cultivation, to conservation and ecotourism. Future research should focus on the role of institutions in producing space for tourism for and within parks at the local level, especially in developing contexts.
\end{abstract}

Keywords: Tourism; Conservation; Space; Institution; National Forest Parks; China 
The role of institutions in the production of space for tourism: National Forest Parks in China

\section{Highlights: Forest Policy Economics}

- Explored the role of institutions in producing tourist-consuming space from woodharvesting space in National Forest Parks (NFPs) in China.

- Rich descriptive case study of how institutional changes mirrored the dynamic role in NFPs played by the state, capital and society in China.

- Findings demonstrate NFPs transitioned form a regional economic development tool to a mixture of economic, social, political and ecological requirements.

- A three-phased conceptual triad reflecting the shift in the state, capital and society in NFPs in China from 1982 to 2014 is presented.

- Future research should focus on the interaction between the state, capital and society at the local level. 


\section{The role of institutions in the production of space for tourism:}

\section{National Forest Parks in China}

\section{Introduction}

Recreation and tourism is a widespread phenomenon in natural areas (Elands and van Marwijk, 2012). In many locations around the world forests have been transitioned to tourism at the expense of more utilitarian interests such as wood harvesting (Luo and Bao, 2013). The transition of forest landscapes to state governance has not been a smooth process, with considerable debate between state agencies and local residents involved in establishing protected areas (Blicharska and Van Herzele, 2015; Roth, 2008). As such, policy on the production of space and the

provision of sustainable livelihoods for local people has emerged as an important aspect of forest conservation (Roth, 2008). Both are constantly dynamic, evolving in conjunction with associated social, political, economic and ecological processes (Mels 2002). Lefebvre (1991: 49) noted that natural space is part of "the invisible fullness of political space" mediated by "knowledge, technology, money, precious objects, words of art and symbols" (Lefebvre, 1991: 51). Nevertheless, there has been limited research on the role of institutions in the production of space for nature based tourism in national forest or parks, especially in countries experiencing periods of rapid economic growth or political reform.

By the end of 2014, China had created nine different types of parks, consisting of more than 2,708 national-level protected areas, managed by different government agencies. The principal types are Forest Parks, Nature Reserves, Geoparks, Wetland Parks, Mining Parks, Marine Parks, Historic and Interest Areas, Water Reserve Parks and Cultural Parks. Each type may be administered at the national, provincial or local level. A total of 791 National Forest Parks (NFPs) have been constructed and managed by the China State Forestry Administration (CSFA) since 1982, covering $1.25 \%$ of China's terrestrial surface. The CSFA (2015) reported that forest recreation received more than 700 million domestic and foreign visitors and over US\$11 billion in revenue, playing a vital role in economic sustainability at the national and regional level.

Despite considerable growth in the number of parks in China, there has been limited inquiry into the role of institutions in the production of space for nature based 
tourism in national forest parks (NFPs). China is an exceptionally interesting case institutional issues have affected the (re)configuration of space (Ma and $\mathrm{Wu}, 2005$, McGee, 2009, Sofield and Li, 2011).

Consequently, the aim of this research is to explore the production of space for tourism in NFPs in China from an institutional perspective. To achieve this aim this research is driven by three key objectives. First, this research sets out to understand the core drivers in national-level policy that led to the production of NFPs driven by tourism. Second, this research explores the interaction between the state, capital and society in the production of NFPs over different national-level policy cycles. Third, this research seeks to develop a conceptual model illustrating the interaction between the state, capital and society that led to the production of space for NFPs for testing and application in other contexts. The contribution of this manuscript lies in a rich case study of the role of institutions in the production of space for tourism to natural and protected areas. Specifically by using an in-depth exploration of government policy documents, this paper focuses on how the production of space for tourism in NFPs has been dynamically shaped from an institutional perspective, at the national level

\section{Literature Review}

\subsection{Conceptualizations of space}

Previous research on the concept of space has predominantly been conceptualized through the lens of western social science (McGee, 2009; Roth, 2008; Soja, 1989). Core theoretical approaches have been developed through the discipline of geography, where there has been a long-standing belief that the concept of space is shaped from the social meaning of peoples' lives (Harvey, 1973; Lefebvre, 1991; Massey, 2005; Soja, 1989), with space no longer appearing to be a static platform of social relations (Yrigoy, 2014).

Seminal work which sought to examine the relationship between space and social change was developed by Lefebvre (1991). He defined spatiality as "both the medium and outcome" of situated human agency and systems of social practice, proposing a unitary theory of space that ties together the physical, the mental and the social, which introduced a "triad" for the production of space (Lefebvre, 1991, 2003; Lefebvre and Enders, 1976). Simultaneously, space is both a spatial practice, including an externalized, material environment, as well as a process by which materiality is 
produced. Concomitantly, a representation of space is the verbal description, (Lefebvre, 1991). Alternately, space of representation is space that is symbolic, subjective, "qualitative, fluid and dynamic" (Merrifield, 1993 p .11). Furthermore, Lefebvre (1991: 84) denoted that national parks, similar to NFPs, are "products of an activity that involves the economic and technical realms but which extends well beyond them, for these are also political products, and strategic spaces". Recent research often applies Lefebvre's (1991) spatial triad as a theoretical framework for empirical research on the production of space (Buser, 2012; Frisvoll, 2012; Hossain, 2012; Leary, 2013; Mels, 2002; Roth, 2008). Despite the various interpretations, the spatial triad has been criticized for its intuitive simplicity, conceptualization and totality (Gottdiener, 1993; Leary, 2013; Schmid, 2008; Ye et al., 2014). In addition, Lefebvre (1991) does not account for complex interactions that occur in the rapidly shifting dynamic nexus of the spatial triad, resulting in difficulties interpreting and adapting the concept (Merrifield \& Lefebvre, 2000).

\subsection{Interplay between the state, capital and society}

Empirical studies have concluded that space is often used as a political tool for state regulation (Roth, 2008), primarily focusing on the production of a social world to commodify the productive factors and livelihood assets (Butler, 2009). Arguably, the concept of "social" in spatial production should be considered in a broader sense, reflecting all social actions and relations (Ye et al., 2014). This assertion leads to the conclusion that space is constantly dynamic, evolving in conjunction with associated social, political, and economic processes (Roth, 2008). As a result, the concept of space is often divided into three interrelated subcomponents - political, economic and social - which are also intricately intertwined with the state, capital and society (Schmid, 2008; Ye et al., 2014).

Historically, policies implemented by states tend to prioritize the production of space in specific locations and at precise scales (Brenner, 1999). Consequently, policy initiatives have been found to neglect, marginalize or exclude other viable locations (Jones, 1999). Space is inherently connected to emergent political strategies that are oriented towards the creation of new geographies, created by state policy and political-economic life (Brenner, 2004). For instance, Harms (2011: 238) asserted that "state power endures only by virtue of violence directed towards a space", with "idealized conceptions of spatial order", which would have a substantial impact on 
tourism development processes by political philosophy and ideology (Hall, 1998). In a study on Swedish national parks, Mels (2002) argued that empty space represents the understanding of national parks as "pure" nature; organic space links nature to the conception of "Swedishness" and optical space embodies the visual immediacy by a multimedia dialectic of images, texts and maps respectively.

In addition, previous studies have identified capital as critical in generating economic interest in the production of space (Harvey, 1982; Lefebvre, 1991; Yrigoy, 2014). However, capital has been found to have the potential to produce space solely to produce a profit (Yrigoy, 2014). Market-based modernization and economic growth strategies have been critiqued as viewing land as a commodity, rather than as a social-ecological resource for livelihood generation (Hansen, 2013; Lefebvre, 1991; Roth, 2008). Inquiry has also centered on the potential dichotomy between state and society, with flexible spatial strategies demonstrated to strengthen social relationships between local communities and state conservation agencies (Roth, 2008). Negotiation between core stakeholder groups has been identified as a key part of park-people conflict, with outcomes intertwined with community sentiment towards the production of space (Roth, 2008).

\subsection{Political economy in tourism}

The "political economy of tourism" emerged in the early 2000s (Nunkoo \& Smith, 2013), yet arguably still remains relatively conceptually underdeveloped within the tourism field (Yrigoy, 2014). The production of space has been applied to tourism in recent times as a means to analyze the political economy and develop new, special strategies for landscape conservation. For instance, Roth (2008) argues for the reconceptualization of spatial conflict among parks and people, noting the production of space should be viewed not as a process whereby state (abstract) space erases or destroys local (complex) space, but as a moment of spatial reorganization resulting from the continual process of state and local spatial production. Hansen (2013) noted that in Thailand spatial conflict often emerges through tensions between the imposed conservation objectives of World Heritage Sites and the subjective space of users and inhabitants. Yrigoy (2014) found that the "spatial fix" of capital could not be explained without including the state and local agencies in tourism. Thus, institutional mechanisms need to be created to encourage active state and community participation in tourism planning and governance (Hansen, 2013; Roth, 2008; Ye et al., 2014; Yrigoy, 2014). 
Although there is no universally agreed school of thought institutions are often considered as the rules of the game in a society or, more formally, are the humanly devised constraints that shape human interaction (North, 1981, 1990). Broadly, a plethora of literature documents a strong connection between economic institutions and economic performance in different countries (Knack and Keefer, 1995; Mauro, 1995). With growing recognition of the need for theory that can account for institutional change, there has been a subsequent increase in tourism literature in relation to institutional research (Bramwell, 2006; Bramwell and Cox, 2009; Bramwell and Lane, 2011, 2014; Bramwell and Meyer, 2007), specifically tourism transformation (McLennan et al., 2012, 2013, 2014) and governance (Hall, 2011; Hultman and Hall, 2011). Within these two interconnected bodies of knowledge it has been argued that institutional change is a critical factor with the capacity to drive tourism development (Dredge \& Jenkins, 2011).

Institutional theory is a broad interdisciplinary field, with early foundations in the management and policy literature. Early theoretical discourse centered on the use of organizations as technical instruments, designed as a means to achieve specified goals (Scott, 1987). However, more contemporary research has identified institutional theory "as an approach to understanding organizations and management practices as the product of social rather than economic pressures" (Suddaby, 2013, p. 379). This has become an increasingly popular perspective in management theory for an ability o account for organizational behavior that often seems to defy economic rationality. Importantly for this manuscript institutions have been identified in previous studies as core drivers of policy, especially at the national level, connecting with how space is produced, reconfigured and transformed (Braverman, 2015).

For instance, interactions between state, capital and society have the capacity to produce different "spatialities" (Lefebvre, 1991; Mels, 2002; Roth, 2008). Nevertheless, theory surrounding the production of space requires conceptual clarity and refinement, in addition to enrichment via in-depth descriptive case study analyses in different geographic contexts (Roth, 2008; Ye et al., 2014; Yrigoy, 2014). Specifically, the application of core concepts central to the production of space has received limited attention in socialist states, as well as in developing economies (McGee, 2009; Nguyen and Locke, 2014; Roth, 2008). In addition, there is limited research on the production of space to support national-level policy that focuses on developing specific economic sectors, such as tourism, to diversify areas experiencing 
a decline in traditional industries, such as forestry.

\section{Methodology}

\subsection{Background to case study}

Over the past 30 years, the economic, social and institutional environment in China has changed profoundly. As a result of shift in government policy, particularly surrounding opening up and reform, tourism in China has been encouraged to forge diplomatic relationships (Zhang \& Xiao, 2014). Consequently, different types of attractions have been developed to meet the needs of tourists, with nature based tourism emerging in prominence.

Nature based tourism in China is designed to preserve and showcase unique landscapes, rich in history and culture (Wang et al., 2012). However, the process of the growth, development and expansion of nature based tourism opportunities is deeply entrenched in traditional Chinese approaches to governance. As such, the reconstruction of space for parks, and reorganization of the spatial structures within parks has synergies, as well as differences, with the approaches documented in western literature (Luo \& Bao, 2013; Zhang \& Xiao, 2014). Table 1 displays China's classification system for National Parks.

\section{$<$ INSERT TABLE 1 ABOUT HERE $>$}

As displayed in Table 1, in China, to the end of 2014 there are 2708 parks, including 791 NFPs. This research focuses on the creation and allocation of space for NFPs, which first emerged in the early 1980's to reform, open up and reinvigorate China's forests. Although not the largest type of national park in China, NFPs are emerging in importance for domestic and international visitors, and thus have become vital for economic sustainability at both the national and regional level (Luo \& Bao, 2013). At the provincial level, the local government is responsible for the construction of space for parks.

\subsection{Data collection and analysis}

Systematic approaches to reviewing policy documents are becoming increasingly popular in studies on the governance of natural areas, especially from an institutional 
perspective (Arts and Buizer, 2009; Leipold, 2014). To explore the production of space for tourism in NFPs in China a systematic review of policy as well as other key documents was undertaken. Policy documents were identified using a systematic online search of electronic databases, using a series of 15 key words derived from previous literature and consultation with experts (Hu and He, 2012; Tang, 2014). Key words included 'modernization', 'diversification', 'economy', 'state-owned enterprise', 'sustainable development', 'ecological cultivation', 'forestry' and 'tourism', 'forest park', 'forest tourism', 'state-owned forest farm', 'ecological forestry' and 'wellbeing forestry' 'ecotourism' and 'nature conservation'. Databases searched included the Central Committee of the Communist Party of China's (CCCPC) database to identify policies and regulations for NFPs at the national level, the database of the CSFA, by China National Tourism Administration (CNTA), respectively.

Databases were searched between October 2014 and May 2015, with three sequential stages used to collect data. First, 15 policy documents (including nine reports and six leaders' speeches) were collected from the CCCPC database. Second, 44 annual reports between 1949 and 2012 related to forestry and tourism were collected from the China National Knowledge Infrastructure (CNKI) network, including 26 speeches from leaders of the CSFA and CNTA,. Third, nine reports and speeches were collected from the official websites of the CSFA and CNTA between 2012 and 2014. Finally, data from four major events demonstrated to influence Chinese society were added to the data set. This process resulted in 68 documents exported into MS Excel for discourse analysis in Table 2.

\section{$<$ INSERT TABLE 2 ABOUT HERE $>$}

The MS Excel database was scrutinized to discern the relevance of the information to NFPs by utilizing two key techniques. First, the documents were reviewed by an independent party to determine whether the information collected was relevant to NFPs. Second, following an approach by Moyle et al., (2014) a select sample of articles was manually scrutinized for relevance to national forest parks. A two tiered process was used to systematically analyze the documents collected (Ritchie \& Spencer, 2002). First, documents from the CCCPC were used to provide a background to the broader historical and societal context in China (Bowen, 2009). 
Second, specific documents from CSFA and CNTA data were used to provide further key words on NFPs in different stages were manually derived by data crosschecking (Creswell, 2009). Results reported are aggregated rather than presented as source-specific evidence, as often the quotes selected do not appear in one particular document, but can be found in several documented sources. As such, data is presented in chronological order, often cited as a more appropriate way of presenting institutional change over the long term rather than a traditional thematic analysis (Fitzgerald, 2007).

\section{Results}

Findings of this research demonstrate that National Forest Parks (NFPs) are a concentrated reflection of national major principles and policies in forestry. According to the memorabilia after the reform and opening up of China, the third plenary session of the 11th CCCPC in 1978, Deng Xiaoping's south talk in 1992, the 16th the National Congress of CPC (NCCPC) in 2002 and the 18th NCCPC in 2012 have been identified as key events affecting the process of the economic, political and social development in China (China Reform Data, 2015). To illustrate the critical role of these four key events, as well as national level policy, in the development of NFPs in China, the structure of the results is divided into five subsections; prior to the establishment of NFPs (1949-1981), the state-led pilot stage (1982-1991), state deteriorating and capital advancing (1992-2001), the capital's acceleration and regulation strengthened by the state (2002-2011) and the intersection of the state, capital and society (2012-present), respectively (Fig.1).

\section{<INSERT FIG. 1 ABOUT HERE>}

\subsection{Prior to the establishment of National Forest Parks (1949-1981)}

In 1949, at the first plenary session of the Chinese People's Political Consultative Conference (CPPCC), the $34^{\text {th }}$ article stipulated that the "policy is to protect forests and develop forests systematically" (CSFA, 1986a: 608). The period prior to the establishment of NFPs was characterized by the construction of "forest farms" (CSFA, 1986a: 608), especially during the 1950s, with the primary intention of harvesting wood after a 20-year growth cycle. However, at the end of the 1970s forest farms 
entered a tumultuous period with the characteristics of an "economic and ecological crisis" (Luo, 1978: 591) due to an oversupply of workers, low productivity and issues with accessibility to key areas of the forest. This realization sparked an ongoing debate over the core purpose of forests in China, with a specific emphasis on how to leverage the unique environmental and cultural values in forests to overcome key economic, environmental and social issues.

As a result of this debate the third plenary session report of the $11^{\text {th }}$ CCCPC in 1978 argued that policy reform must be undertaken in a partnership between "the party and the state to drive modernization" (CCCPC, 1978: n.p.). Deng Xiaoping, who was responsible for China's reform and opening-up policy, made the initial recommendation to develop and expand the tourism sector, especially for international tourism (He, 1999). As a result of this national-level policy directive CSFA commenced developing NFPs to open up China's forests for nature-based tourism. Under the direction of reform, development and revitalization forestry diversification, focusing specifically on logging, herbing and fishing, accelerated the development of NFPs. Guidelines were developed, setting a prescribed governance structure for NFPs to "establish and improve production in order to develop diversification" (Zhao, 1980: n.p.) into agriculture and tourism.

As a consequence of economic diversification the concepts of "forest tourism" and "forest park" (CSFA, 1986b: 149) first emerged in 1980, with eight forest farms selected as the first pilot parks for forest tourism in 1981. Initial pilot sites were selected due to a unique geological landscape, biodiversity values and tourism potential.

\subsection{Policy cycle 1: The state-led pilot stage (1982-1991)}

In 1982 the opening report of the $12^{\text {th }}$ NCCPC stated that "the modernization of agriculture, military, science and technology would be gradually realized" (CCCPC, 1982: n.p.), transforming China into a civilized and democratic socialist state. During policy cycle 1 , forestry was identified as an "urgent task" (CCCPC, 1986: 26) with debate ensuing over "forest conservation and forest development" (Dong, 1986: 645). After a 20-year growth cycle the forest in Zhangjiajie state-owned forest farm matured. However, due to the inaccessibility of roads, logging experienced a period of decline. Meanwhile, the unique geological landscape coupled with community desire to travel resulted in Zhangjiajie in Hunan province being established as a pilot project 
for NFPs. The opening of the Zhangjiajie NFP created a new chapter, not only for Zhangiajie NFP not only created the potential to generate economic revenue for adjacent communities, but also provided confidence to reform China's forest industry, with nine further pilot NFPs developed from 1982-1991 (Table 3).

\section{<INSERT TABLE 3 ABOUT HERE>}

Under the Communist Party of China's direction of reform the CSFA began to initiate the development of tourism within China's forests. Policy direction shifted "to achieve four key changes in forestry, specifically shifting the traditional closed forestry into modern forestry and providing economic, ecological, and social benefits" (Dong, 1986: 646). As a result, NFPs became an important element in diversifying regional economies, with governments beginning to recognize that investment in tourism had the potential to generate economic benefits. For example, Qiandaohu NFP received 23.22 million tourists, including 4,566 international tourists, from 1982-1988. Furthermore, in 1988 Qiandaohu NFP generated tourism revenue of over US\$2 million for the local economy.

\subsection{Policy cycle 2: State deteriorating and capital advancing (1992-2001)}

In 1992 development was identified as fundamental, with China directed to concentrate on economic prosperity and not dwell on the issues of "capitalism" or "socialism" in Deng Xiaoping's South Talk (CCCPC, 1992, n.p.). The $14^{\text {th }}$ and $15^{\text {th }}$ NCCPC set out to establish the system of a socialist market economy to develop national productivity, due to the realization that "the market plays a fundamental role in resource allocation" (CCCPC, 1997: n.p.). In addition, fiscal policy reform shaped the local government to be enterprise-led, viewing land in NFPs as an asset that needed to be developed, with the potential to produce commercial benefits to improve livelihoods. During this period it was advocated that "the reform of state-owned forest farms should be guided by the market, without intervention" (Xu, 1993: 19).

Concurrently, China's tourism industry was identified as a new national economic pillar. Based on the successful pilot of forest tourism in NFPs, the CSFA identified that forest tourism was an effective method for diversification and comprehensive utilization of state-owned forest farms (Xu, 1993). As such, forest 
farms were transitioned into NFPs, with construction considered a labor-intensive and As a result of this recognition a further 136 NFPs were approved by CSFA at the end of 1992. In addition, Zhangjiajie NFP was designated into the list of World Natural Heritage Sites, which further stimulated the transformation of stated-owned forest farms into NFPs.

By 1998 domestic and international tourism was reinforced as one of the cornerstones of the national economy; as emphasized by the implementation of the two-day weekend in 1995 and the Golden Week ${ }^{1}$ in 2000. During the period of 1992-2001 the number of international visitors to China increased from 38 million in 1992 to 89 million in 2001, with estimated revenue of US $\$ 3.95$ billion to US $\$ 17.79$ billion for inbound tourism (CNTA, 2014). In addition, domestic tourism increased from an estimated US\$25-350 billion, with tourism as a percentage of GDP increasing from $0.94 \%$ to $5.2 \%$ (CNTA, 2014). NFPs rapidly emerged as one of the most popular tourism attractions in China, leading to a number of physical as well as perceptual impacts. For instance, in 1998 UNESCO pointed out that Zhangjiajie NFP:

“...has become a surrounded island between agricultural production and rapidly developing tourism, where the tourist facilities [have] developed in an uncontrolled manner. Whether it has done harm to bio-diversification is unknown. But the influence on the aesthetic value is obvious." (UNESCO, 1998, n.p.)

This criticism from UNESCO led to the conclusion that the emphasis on the economic benefits should not come at the expense of ecology and society (Xu, 1993). Specific criticism was centered on the flood of the Yangtze River Basin, driven by long-term deforestation in the upper and middle Yangtze River. These events led to a shift, with NFPs designated to provide environmental and social benefits (especially in protecting endangered species and preserving unique culture and heritage) in addition to the economic benefits that were already evident.

During the second policy cycle there was a movement to formulate and improve laws and regulations regarding the production of space for and within NFPs. Consequently, the Forest Park Management Office was established, including a branch designed to manage tourism and its associated development. Policy directives

\footnotetext{
${ }^{1}$ The Golden Week is a collection of three national holidays - including the Spring Festival, Labor Day (1 May) and National Day (1 October) - within seven days by combining them with well-placed weekends. They have become China's three busiest holidays, commencing in 1999, and have made changes to two holidays with the abolishment of Labor Day in 2008.
} 
created an institutional framework, standardizing the approval procedure to meet the requirements of forest tourism and provide guidelines for the production and design of NFPs.

\subsection{Policy cycle 3: Capital's acceleration and regulation strengthened by the state} (2002-2011)

In 2002 the report of the $16^{\text {th }}$ NCCPC concluded that the concept of "sustainable development" should be implemented. Core to this goal was improving the ecological environment and the efficiency of resource utilization, as well as increasing the connection between humans and nature (CCCPC, 2002). Subsequently, during policy cycle 3 forestry policy shifted towards "sustainable development" and "ecological construction" (CCCPC, 2003). This led to a decline in traditional timber production and an ecological focus to support the growth of domestic and international visitors, as well as other core development functions (Zhou, 2005). Clear regulatory guidelines were set up to regulate the approval and management of building, cancelling, merging and changing the scope of business and subordinate relationships for NFPs and the regulation of NFPs, including a code for the Master Planning of NFPs.

In 2007 the concept of "ecological civilization", was integrated into the policy sphere to inform industrial structure, economic growth and consumption mode, with a specific focus on energy reduction and resources saving (CPCCC, 2007a). NFPs were mandated to provide economic, environmental and socio-cultural benefits for local communities in China (Jia, 2006). Tourism was anchored heavily towards this initiative, with capital investment into NFPs encouraged to cater for domestic and international visitors. For instance, a private investment firm spent US\$150 million to develop infrastructure to support visitation to Tianmenshan NFP in Hunan province. Although privately-funded, development assisted in meeting the demands of increased visitation; however, it also led to adverse impacts on the environment, such as a loss of unique flora and fauna, as well as negative impacts on landscapes (Luo and Zhong, 2014: 20).

To mitigate this issue China designated two "forest tourism experimental demonstration zones" in Wenzhou (2010) and Hainan (2011) (CSFA, 2012). The purpose of these two key zones was to explore and encourage innovation in

\footnotetext{
${ }^{2}$ Ecological cultivation refers to the cultural ethics forms initiated by the harmonious co-existence, virtuous cycle, comprehensive development, and continued prosperity between man and nature, man and man, and man and society (CPCCC, 2007a).
} 
development models, management systems and operating mechanisms, and to create best practice guidelines surrounding the production of space for forest tourism. In 2012 a cooperation framework agreement on promoting the development of forest tourism signed by the CSFA represented a historic step in cooperation designed to jointly promote forest tourism development and ecological civilization (CSFA, 2012).

\subsection{Future prospects: Intersection of the state, capital and society (2012-present)}

In 2012 the $18^{\text {th }}$ NCCPC reiterated the construction of an ecological civilization as the long-term plan, concerned with the well-being of the people and the nation's future (CCCPC, 2012). Environmental issues, such as smog, became an increasing concern for the public, with an improvement in the standard of living leading to a shift in public attention towards the environment. Indeed, the public's desire to enhance China's environment became a catalyst for the CPC to adjust policy towards: "...strengthening the construction of ecological civilization and environmental protection, and promoting [a] green and carbon lifestyle just as an economic issue. There are a lot of politics" (CCCPC, 2014: n.p.).

This policy shift has potential implications for the production of NFPs, particularly in relation to their ecology and well-being (Zhao, 2013). NFPs have now emerged as the platform to build an ecological civilization to enrich the lives of Chinese people. Furthermore, the China-specific national park system is currently in the preliminary stages of development, underpinned by principles of "national ownership, universal access and safeguarding ecology for future generations to enjoy and experience" (CCCPC, 2013: n.p.).

\section{Discussion}

Previous literature has identified that the production of space can play a significant role in shaping the character of capitalist and socialist society (McGee, 2009; Nguyen and Locke, 2014; Su and Teo, 2008; Ye et al., 2014). This study has identified that the concept of space is no longer a static platform of social relations, but embraces constitutive dimensions, which are historically produced, reconfigured and transformed. Consequently, this research found that NFPs are both an outcome of social, political, economic and ecological processes, and a medium facilitating the interplay between the state, capital and society. This research unearthed that the interaction between the state, capital and society plays an important role in the 
production of space for tourism within NFPs. However, this research also revealed differences exist in the role that the state, capital and society play in China.

The representation of space was analyzed using policy documents (Buser, 2012; Frisvoll, 2012; Hansen, 2013; Leary, 2013; Lefebvre, 1991; Nguyen and Locke, 2014). Indeed, with the gradual adjustment to national development strategies this research found that forestry development strategies for NFPs transformed and continually created "idealized conceptions of spatial order" (Harms, 2011: 238). Key words derived from the ideology for NFPs covered wood harvesting, economic diversification, modern forestry, ecological cultivation, well-being and conservation. Results of this research supported the connotation that tourism development is an essentially political concept, which will have a substantial impact on the production of space as being reductive in its practice (Hall, 1998; Hansen, 2013; Lefebvre, 2003; Roth, 2008). In addition, this research identified that institutional change in NFPs mirrors that national parks are not "pure" nature (Mels, 2002), but rather the result of a complex interaction between the state, capital and society driven by institutional shifts in policy at a national level. Similar research has identified that forests are transitioned from the primacy of wood harvesting to sustainable development, including tourism, biological diversity and environmental education in Australia (Dargavel, 1998), Korea (Bae et al., 2012), Thailand (Roth, 2008) and Mexico (Klooster, 2003). In addition, there exists differences in the driving forces behind forest transition, for instance, findings of this research demonstrate that NFPs are jointly shaped by the state, capital and society with different roles played in each of the policy cycles.

This research discovered that tourism within NFPs was initially conceived as a tool for modernization and economic growth in the 1980s, and then gradually added to a multi-value image with conservation, education, enjoyment, health and political benefits for visitors and surrounding communities. Extant knowledge also supports the role of parks in economic and ecological aspects in urban and rural development (Buser, 2012; Frisvoll, 2012; Halfacree et al., 2004; Moyle \& Weiler, 2016; Roth, 2008). In addition, the role of tourism in national parks has evolved in other nations following a similar pattern to that in China. For instance, tourism as a core economic driver is similar to the initial development of Canadian National Parks (Eagles and McCool, 2002; Frost and Hall, 2009), which have been regulated by the central 
government to meet the increasing demand of tourism. However, the production of space is different from that used in the United States for wilderness, conservation, education, enjoyment and spiritual purposes (Eagles and McCool, 2002; Frost and Hall, 2009), and other European countries (e.g. Sweden) for unity and patriotism (Mels, 2002).

Previous research has found that forest transition is confirmed by a major driving force, for instance government-led reforestation policy (Dargavel, 1998; Bae et al., 2012), the inflow of capital (Gotham, 2002, Leary, 2013; Yrigoy, 2014), and local socioeconomic change (Klooster, 2003; Roth, 2008). In China the official spatiality of NFPs is shaped by the interaction between the state, capital and society. According to the Constitution of the CPC, it is "the core of leadership for the cause of socialism with Chinese characteristics" and represents "the fundamental interests of the overwhelming majority of the Chinese people" (CCCPC, 2007b: n.p.). Thus, as the representative of the people authorized by the Constitution, the $\mathrm{CPC}$ introduced the concept of NFPs to meet the needs of society's economic development in the early 1980s.

Due to the relatively low influence of capital, the state as a major investor constructed a large number of tourism facilities in piloted NFPs in China; in turn, the increasing revenue from these NFPs stimulated the state to establish more NFPs. This reflects the characteristics of top-down state control in socialist countries under a planned economy. The CPC constructed a socialist market economy in the 1990s due to the realization that the market plays a fundamental role in resource allocation. Following this, the state strengthened NFPs as an important asset to develop the regional economy under its fiscal policy. Although capital not only produced a variety of tourist attractions and infrastructure in NFPs, the state and capital changed the materiality of the environment and the appropriation of sites depended by local people by the physical interventions in NFPs (Buser, 2012; Gottdiener, 1993; Hansen, 2013; Roth, 2008; Su \& Teo, 2008). International organizations, for instance, UNSCO, played a positive role in conservation in NFPs acknowledged by the state to regulate the capital. Generally, due to the risk of capital over accumulation in NFPs encouraging unstable social and political relations, the state is important in regulating the economic and political systems in order to mitigate potential negative impacts (Bramwell, 2011; Roth, 2008). 
Ultimately, the interaction between the state, capital and society improved the knowledge of locals on the benefits of NFPs. Previous research demonstrates that institutions selected by the state continually modify and even routinely overlook the rights of society (Roth, 2008), for instance the aesthetic, healthy, ecological and economic value of the forest (Balassiano, 2011; Roth, 2008; Ye et al., 2014). The spatial conflict often emerges between the objective for the conservation of ecological sites and the subjective space of local society (Hansen, 2013). A struggle for rights can be the source of transformation (Frisvoll, 2012; Hossain, 2012; McLennan et al., 2014) that produces a space which can be used to support sectors, such as tourism, and provide benefits to adjacent communities (Su and Teo, 2008).

Consequently, (as seen in Figure 2) the interplay between the state, capital and society in NFPs in China could be divided into three stages. From 1982 to 1991, the state not only gained the economic benefits by establishing NFPs, but made vast investment to construct the infrastructure in NFPs in China. The society however was not independent from the state. From 1992 to 2001, NFPs became the platform between the state and the capital, due to the role of capital as one of important methods of resource allocation in the economy. Following this, the capital over-accumulation in NFPs was found to have a negative impact on the environment and culture and encouraged unstable social and political relations between the state, society and capital. Likewise, the capitalist modernization of NFPs not only accelerated the accumulation of capital as an economic apparatus but also improved the understanding of forestry use and conservation from the perspective of the state and society

After 2002, society gradually separated from and reshaped the state, which incrementally adjusted to provide people increased access to public space, such as NFPs, with environmental education and conservation core principles underpinning development. In addition, the increasing demands from society stimulated the development of infrastructure and services in NFPs, ensuring products provided societal benefits (Moyle, Weiler \& Moore, 2014). Figure 2 summarizes a three-phased conceptual triad reflecting the shift in the state, capital and society in NFPs in China from 1982 to 2014. 
Existing research on the production of space primarily documents the characteristics that exist at a certain point in time. As seen in Figure 2, the longitudinal assessment presents a core contribution to extant knowledge Hansen (2013, Lefebvre (1991) and Roth (2008) find that market-based modernization and economic growth strategies view land as a commodity, rather than as a social-ecological resource for livelihood generation. Buser (2012) suggests that "lived space" is indicative of a post-political condition where hegemonic vision, discourse and ideology deny a robust local democracy. In essence, NFPs are both an outcome of and a medium with the capacity to influence social, political, economic and ecological processes.

\section{Conclusions}

This research found the production of space for tourism within NFPs as abstract, enmeshed in a regime of highly-specific conceptions of the role of the state, capital and society. These conceptions have the potential to distract from gaining a deep understanding of the multifarious natural and cultural phenomena of NFPs, specifically the complex interplay between the state, capital and society identified in this paper. By examining shifts over three different policy cycles this research found that forests in China were initially used for pragmatic interests, such as logging, to sustain regional economies. However, over time more sustainable policies were implemented, with the influence of the state, society and capital fluctuating over different periods at the national level. Importantly, this research discovered that the state, capital and society provide a theoretical lens through which to explore the role of institutions in the production of NFPs driven by tourism, especially over a longitudinal time period.

At a theoretical level this paper demonstrates how the state, capital and society interact to shape the spatiality of NFPs in China from a planned economy to state-controlled capitalism. However, the strength of the contribution of knowledge is the rich, descriptive case study of how institutions have shaped the production of space for nature based tourism in China. The state introduced the ideological concept of NFPs through policy documents to create the spatial imagery for capital and society in NFPs. Concomitantly, this paradigm shift produced a combination of economic, ecological, social and political benefits. Previous studies have found that spatial conflicts emerge through tensions between the subjective space of the actors from 
society and capital. In this body of work the objective space of landscape conservation is controlled by the state through developing policy based on democracy, equality and social justice.

In the case of this research, capital in NFPs accelerated the separation of state and society. Meanwhile, knowledge produced as a result of the interaction between the state, capital and society resulted in society playing a fundamental role in the production of NFPs, becoming a pillar in the spatial triad (see Figure 2.). This research found that institutional change mirrors the production of NFPs driven by tourism. This is especially true for the initial conceptualization as an ideological space in national development for the control of capital and society, to being an instrument to balance the power relationship between capital and society introduced by the state. Thus, a key contribution of this research is that the process and characteristics of the production of NFPs from state, capital and society are de-structured in a Chinese context.

In practice, capital not only creates new spaces or landscapes for the public but has the potential to simultaneously damage the natural environment and ecological system. With societal demands increasing and diversifying, the capacity of negotiation and resistance to the state and capital is increasing. Thus, all levels of government should maintain a balance between the state, capital and society in producing NFPs. In addition, all stakeholders should be consulted during the process of planning and implementing related laws and regulations to control the scope of capital in NFPs, as gatekeepers for common resources in the long-term.

Future research is needed on the relationship between the state, capital and society at the micro-level. In particular, future inquiry should be directed towards state spatiality, specifically how space is actively produced and transformed through socio-political struggles at various geographical scales. Such studies should consider how the rights of society have been impacted by the development of national forest parks. In addition, protected areas are affected by different actions from the state, capital and society. In China, marketization and globalization have accelerated the decentralization of the government. Thus, methods used by different governments to stimulate national and regional economic growth also require further research. Finally, this manuscript did not assess if the development of other networks of protected areas influenced national level policy and development for tourism. As such, future research in this space would also add considerable value to the literature. 


\section{Acknowledgements}

The authors would like to acknowledge Professor Susanne Becken and Dr Char-Lee McLennan for their comments and feedback.

\section{Funding}

This work was supported by the: Special Fund for Forest Scientific Research in the Public Welfare, under Grant number 201404314; China Scholarship Council Foundation, under Grant number 201408430015; China Postdoctoral Science Foundation, under Grant number 2014M550887; China National Tourism Administration Young Expert Fund, under Grant [number TYEPT201437]; Hunan Province Philosophy and Social Science Fund, under Grant number 14JD68; and Hunan Province Education Science Twelfth-Five Planning Fund, under Grant number XJK011QXJ003. 


\section{References}

Bae, J. S., Joo, R. W., Kim, Y.S., 2012. Forest transition in South Korea: reality, path and drivers. Land Use Policy 29 (1), 198-207.

Balassiano, K., 2011. Civic space production and local government capacity: lessons from Muang Klang, Thailand. Sojourn: J. Social Issues in Southeast Asia 26 (1), 58-79.

Blicharska, M., Van Herzele, A., 2015. What a forest? Whose forest? Struggles over concepts and meanings in the debate about the conservation of the Białowieża Forest in Poland. Forest Policy Econ. 57, 22-30.

Braverman, I., 2015. Wild Life: The Institution of Nature. Stanford University Press.

Bramwell, B.,2006. Actors, power, and discourses of growth limits. Annals of Tourism Research 33(4): 957-978.

Bramwell, B. and Cox, V., 2009. Stage and path dependence approaches to the evolution of a national park tourism partnership. Journal of Sustainable Tourism 17(2): 191-206.

Bramwell, B. and Lane, B., 2014. The "critical turn" and its implications for sustainable tourism research. Journal of Sustainable Tourism 22(1): 1-8.

Bramwell, B. and Meyer, D., 2007. Power and tourism policy relations in transition. Annals of Tourism Research 34(3): 766-788.

Brenner, N., 1999. Beyond state-centrism? Space, territoriality, and geographical scale in globalization studies. Theory and Society 28 (1), 39-78.

Brenner, N., 2004. Urban governance and the production of new state spaces in Western Europe, 1960-2000. Rev. Intern. Political Econ. 11 (3), 447-488.

Bowen, G. A. (2009). Document analysis as a qualitative research method. Qualitative Research Journal, 9(2), 27-40.

Buser, M., 2012. The production of space in metropolitan regions: a Lefebvrian analysis of governance and spatial change. Planning Theory 11 (3), 279-298.

Butler, C., 2009. Critical legal studies and the politics of space. Social \& Legal Studies 18 (3), 313-332.

CCCPC., 1978. The communique of the third plenary session of the eleventh CPPCC. Accessed on 23rd May 2015 at http://cpc.people.com.cn. (in Chinese)

CCCPC., 1986. Decision on several questions about preserving forests and developing forests, in: CSFA (Ed.), China Forestry Yearbook (Vol. 1949-1986). 
China Forestry Publishing House, Beijing, pp. 26-30. (in Chinese)

CCCPC., 1992. Accelerating the pace of reform and modernization to make greater success in the construction of socialism with characteristics of China. Accessed on 23rd May 2015 at http://cpc.people.com.cn. (in Chinese)

CCCPC., 1997. Holding the great banner of Deng Xiaoping's theory, and building socialism with the characteristics with china into 21 st century in all aspects. Accessed on 23rd May 2015 at http://cpc.people.com.cn. (in Chinese)

CCCPC., 2002. Building a well-off society in an all-round way and creating a new situation to build socialism with Chinese characteristics. Accessed on 23rd May 2015 at http://cpc.people.com.cn. (in Chinese)

CCCPC., 2003. Decision on accelerating the development of forestry, in: CSFA (Ed.), China Forestry Yearbook (Vol. 2004). China Forestry Publishing House, Beijing, pp. 1-7. (in Chinese)

CCCPC., 2007a. Holding high the great banner of socialism with Chinese characteristics and striving for new victories in building a moderately prosperous society in all respects. Accessed on 23rd May 2015 at http://cpc.people.com.cn. (in Chinese)

CCCPC., 2007b. The Constitution of the CPC. Accessed on 23rd May 2015 at http://cpc.people.com.cn. (in Chinese)

CCCPC., 2012. Firmly marching on the path of socialism with Chinese characteristics and striving to complete the building of a moderately prosperous society in all respects. Accessed on 23rd May 2015 at http://cpc.people.com.cn. (in Chinese)

CCCPC., 2013. Decision on several questions about deepening roundway reform. Accessed on 23rd May 2015 at http://cpc.people.com.cn. (in Chinese)

CCCPC., 2014. The series of important speeches made by Xi Jinping, General Sceretary of CPC. Accessed on 23rd May 2015 at http://cpc.people.com.cn. (in Chinese)

CNTA., 2014. Tourism statistics (1982-2014). Accessed on 23rd May 2015 at http://www.cnta.gov.cn. (in Chinese)

CSFA., 1986a. China forestry memorabilia. China Forestry Yearbook. China Forestry Publishing House, Beijing (in Chinese).

CSFA., 1986b. Stated-owned forest farms and scenic and historic areas, in: CSFA (Ed.), China Forestry Yearbook. China Forestry Publishing House, Beijing, p. 149 (in Chinese) 
CSFA., 2012. Warm congratulations on the 30th anniversary development of Chinese forest park. Accessed on 24th May 2015 at http://www.forestry.gov.cn. (in Chinese)

CSFA., 2015. Statistics for building and operation in National Forest Parks (19822014). Accessed on 24th May 2015 at http://www.forestry.gov.cn. (in Chinese)

Creswell, J. W. 2009. Editorial: Mapping the field of mixed method research. Journal of Mixed Methods Research, 3(2), 95-108.

Dargavel, J., 1998. Politics, policy and process in the forests. Australian Journal of Environmental Management 5 (1), 25-30.

Dredge, D., \& Jenkins, J., 2011. Stories of practice: Tourism policy and planning. Surrey, England: Ashgate Publishing Limited.

Dong, Z., 1986. Strategic thoughts for forestry development and the position and role of forestry in national economy, in: CSFA (Ed.), China Forestry Yearbook (Vol. 1949-1986). China Forestry Publishing House, Beijing, pp. 644-647. (in Chinese)

Eagles, P. F., McCool, S. F., 2002. Tourism in National Parks and Protected Areas: Planning and Management. CABI, Wallingford.

Elands, B. H. M., van Marwijk, R. B. M., 2012. Policy and management for forest and nature based recreation and tourism. Forest Policy Econ. 19, 1-3.

Fitzgerald, T. 2007. Documents and documentary analysis: Reading between the lines. Research methods in educational leadership and management, 2, 278-294.

Foucault, M., 1980. Prison talk, in: C. Gordon (Ed.), Power/Knowledge: Selected Interviews and Other Writings 1972-1977. Pantheon, New York, pp.146-165.

Frisvoll, S., 2012. Power in the production of spaces transformed by rural tourism. Journal of Rural Studies 28 (4), 447-457.

Frost, W., Hall, C. M., 2009. Tourism and National Parks: International Perspectives on Development, Histories, and Change. Routledge, Abingdon.

Gao, D., 1993. Under the guideline of the spirit of 14th CPCCC, we are working hard for forestry to make it be green, livable and rich fast, in CSFA (Ed.), China Forestry Yearbook (Vol. 1992). China Forestry Publishing House, Beijing (in Chinese), pp. 6-11.

Gotham, K. F., 2002. Marketing mardi gras: commodification, spectacle and the political economy of tourism in New Orleans. Urban studies 39 (10), 1735-1756. 
Gottdiener, M., 1993. A Marx for our time: Henri Lefebvre and the production of space. Sociological Theory 11 (1), 129-134.

Hall, M.C., 1998. Tourism and politics policy: power and place. John Wiley \& Sons, Chichester.

Hall, M.C., 2011. A typology of governance and its implications for tourism policy analysis. Journal of Sustainable Tourism 19(4-5): 437-457.

Hultman, J. and Hall, M.C., 2012. Tourism place-making: governance of locality in Sweden. Annals of Tourism Research 39(2): 547-570.

Halfacree, K., 2004. Rethinking 'rurality', in: Champion, T. \& Hugo, G. (Eds.), New Forms of Urbanization: Beyond the Urban-Rural Dichotomy. Ashgate, Aldershot, pp.285-304.

Hansen, M., 2013. New geographies of conservation and globalisation: The spatiality of development for conservation in the iSimangaliso Wetland Park, South Africa. Journal of Contemporary African Studies 31 (3), 481-502.

Harms, E., 2011. Saigon's Edge: On the Margins of Ho Chi Minh City. University of Minnesota Press.

Harvey, D., 1973. Social Justice and the City. Johns Hopkins University Press, Baltimore.

Harvey, D., 1982. The Limits to Capital. University of Chicago Press, Chicago.

He, G., 1999. China tourism industry in fifty years. China Tourism Publishing House, Beijing. (in Chinese)

Hu, Y., \& He, Y. 2012. Evolution of forestry policy in China Since 1949. Journal of Beijing Forestry University (Social Sciences), 11 (3), 21-27, (in Chinese).

Hossain, S. (2012). The production of space in the negotiation of water and electricity supply in a bosti of Dhaka. Habitat International, 36 (1), 68-77.

Jia, Z., 2006. Insisting in using scientific outlook on development to command the overall situation of the work and working hard to put forestry into a new faster and better stage, in: CSFA (Ed.), China Forestry Yearbook (Vol. 2007). China Forestry Publishing House, Beijing, pp. 25-33. (in Chinese)

Jones, M., 1999. New Institutional Spaces: Training and Enterprise Councils and the Remaking of Economic Governance. Jessica Kingsley Publishers, London.

Knack, S. and Keefer, P., 1995. Institutions and Economic Performance:

Cross-Country Tests using Alternative Measures. Economics and Politics 7, $207-227$. 
Klooster, D., 2003. Forest transitions in Mexico: institutions and forests in a globalized countryside. The Professional Geographer 55 (2), 227-237.

Leary, M. E., 2013. A Lefebvrian analysis of the production of glorious, gruesome public space in Manchester. Progress in Planning 85, 1-52.

Lefebvre, H., 1991. The Production of Space. Wiley-Blackwell, Chichester.

Lefebvre, H., 2003. Space and the state, in: Brenner, N., Jessop, B., Jones, M. \& MacLeod, G. (Eds.), State/Space: A Reader. Blackwell, London, pp. 84-100.

Lefebvre, H., Enders, M. J., 1976. Reflections on the politics of space. Antipode 8 (2), 30-37.

Luo, F., Bao, J., 2013. Evolutional process and characteristics of National Forest Parks in China: A perspective of the logic of state, market and society. Economic Geography 33 (3), 164-169 (in Chinese).

Luo, F., Zhong, Y., 2014. Effects of tourism development since 1982 on state-owned forest farms. Journal of Central South University of Forestry \& Technology 34 (5), 107-112 (in Chinese).

Luo, Y., 1978. Accelerating development of forestry, in: CSFA (Ed.), China Forestry Yearbook (Vol. 1949-1986). China Forestry Publishing House, Beijing, pp. 591-594. (in Chinese)

Ma, L.J.C. and Wu, F.L., 2005. Restructuring the Chinese City: Diverse processes and reconstituted spaces, in Ma, L.J.C.and Wu, F.L. (eds.), Restructuring the Chinese City, pp. 1-20. London and New York: Routledge.

Massey, D., 2005. For space. SAGE, London.

Mauro, P., 1995. Corruption and Growth” Quarterly Journal of Economics $110,681-712$.

McGee, T. G., 2009. Interrogating the production of urban space in China and Vietnam under market socialism. Asia Pacific Viewpoint 50 (2), 228-246.

McLennan, C.J., Pham, T.D., Ruhanen, L. M., Ritchie, B. W., Moyle, B. D., 2012. Counter-factual scenario planning for long-range sustainable local-level tourism transformation. Journal of Sustainable Tourism 20(6): 801-822.

McLennan, C.J., Moyle, B. D., Ruhanen, L. M., Ritchie, B. W., 2013. Developing and Testing a Suite of Institutional Indices to Underpin the Measurement and Management of Tourism Destination Transformation. Tourism Analysis 18(2): 157-171.

McLennan, C. J., Ritchie, B. W., Ruhanen, L. M., Moyle, B. D., 2014. An institutional 
assessment of three local government-level tourism destinations at different

Mels, T., 2002. Nature, home, and scenery: the official spatialities of Swedish national parks. Environment and Planning D: Society and Space 20 (2), 135-154.

Merrifield, A., 1993. Place and space: A Lefebvrian reconciliation. Transactions of the Institute of British Geographers, 516-531.

Merrifield, A., Lefebvre, H., 2000. A socialist in space, in Crang, M. \& Thrift, N. (Eds.), Thinking Space. Routledge, London, pp.167-182.

Moyle, B. D, McLennan, C., Ruhanen, L. \& Weiler, B. 2014. Tracking the Concept of Sustainability in Australian Tourism Policy and Planning Documents, Journal of Sustainable Tourism, 22(7), 1037-1051.

Moyle, B. D. \& Weiler, B. 2016. Revisiting the Importance of Visitation: Public Perceptions of Park Benefits, Tourism and Hospitality Research DOI: $10.1177 / 1467358416638918$.

Moyle, B. D. \& Weiler, B. \& Moore, S. 2014. Benefits that matter to managers? An exploratory study with three park management agencies, Managing Leisure, 19(6), 400-419.

North, D.C., 1981. Structure and Change in Economic History. Norton \& Co, New York.

North, D.C., 1990. Institutions, Institutional Change, and Economic Performance. Cambridge University Press, Cambridge.

Nunkoo, R., \& Smith, S. L. 2013. Political economy of tourism: Trust in government actors, political support, and their determinants. Tourism Management, 36, 120-132.

Nguyen, M. T. N., Locke, C., 2014. Rural-urban migration in Vietnam and China: gendered householding, production of space and the state. The Journal of Peasant Studies 41 (5), 855-876.

Ritchie, J., \& Spencer, L. (2002). Qualitative data analysis for applied policy research. The qualitative researcher's companion, 573, 305-329.

Roth, R. J., 2008. "Fixing" the forest: the spatiality of conservation conflict in Thailand. Annals of the Association of American Geographers 98 (2), 373-391.

Schmid, C., 2008. Henri Lefebvre's theory of the production of space: towards a three-dimensional dialectic, in: Goonewardena, K., Kipfer, S., Milgrom, R. 
Schmid, C. (Eds), Space, Difference, Everyday Life: Reading Henri Lefebvre.

Routledge, New York, pp. 27-45.

Scott, W.R., 1987. The adolescence of institutional theory. Administrative science quarterly, pp.493-511.

Sofield, T. and Li, S., 2011. Tourism governance and sustainable national development in China: a macro-level synthesis. Journal of Sustainable Tourism 19(4-5): 501-534.

Soja, E. W., 1989. Postmodern Geographies: The Reassertion of Space in Critical Social Theory. Verso, London.

$\mathrm{Su}, \mathrm{X} .$, Teo, P., 2008. Tourism politics in Lijiang, China: an analysis of state and local interactions in tourism development. Tourism Geographies 10 (2), 150-168.

Tang, X. (2014). The evolution of Chinese tourism development policies (1949-2013): a quantitative perspective. Tourism Tribune, 29 (8), 15-27. (in Chinese)

UNESCO., 1998. The state of conservation of the World Natural Heritage:

Wulingyuan. Accessed on 23rd May 2015 at

http://whc.unesco.org/archive/periodicreporting/apa/cycle01/section2/640.pdf.

$\mathrm{Xu}, \mathrm{Y} ., 1993$. Positively adapting forestry to the needs of socialist market economy, deepening the forestry reform to push it into a new stage with high-yield, high-quality, high-efficiency and sustainability, in CSFA (Ed.), China Forestry Yearbook (Vol. 1993). China Forestry Publishing House, Beijing, pp. 16-21. (in Chinese)

Ye, C., Chan, M., Chen, R., Guo, Z., 2014. Multi-scalar separations: Land use and production of space in Xianlin, a university town in Nanjing, China. Habitat International 42, 264-272.

Yrigoy, I., 2014. The production of tourist spaces as a spatial fix. Tourism Geographies 16 (4), 636-652.

Zhao, S., 2013. Carrying out the spirit of the central government and strengthening reform and innovation to comprehensively improve the level of ecological and livelihood forestry. Accessed on 24th May 2015 at http://www.forestry.gov.cn. (in Chinese)

Zhao, Z., 1980. Several questions to adjust the national economy. Accessed on 24th May 2015 at http://cpc.people.com.cn. (in Chinese)

Zhou, S., 2005. Current situation and tasks for forestry, in CSFA (Ed.), China Forestry Yearbook (Vol. 2006). China Forestry Publishing House, Beijing, pp. 14-20 (in 
Chinese).

1

2

3

4

5

9

10

11

12

13

14

15

16

17

18

19

20

21

22

23

24

25

26

27

28

29

30

31

32

33

34

35

36

37

38

39

40

41

42

43

44

45

46

47

48

49

50

51

52

53

54

55

56

57

58

59

60

61

62

63

64

65 


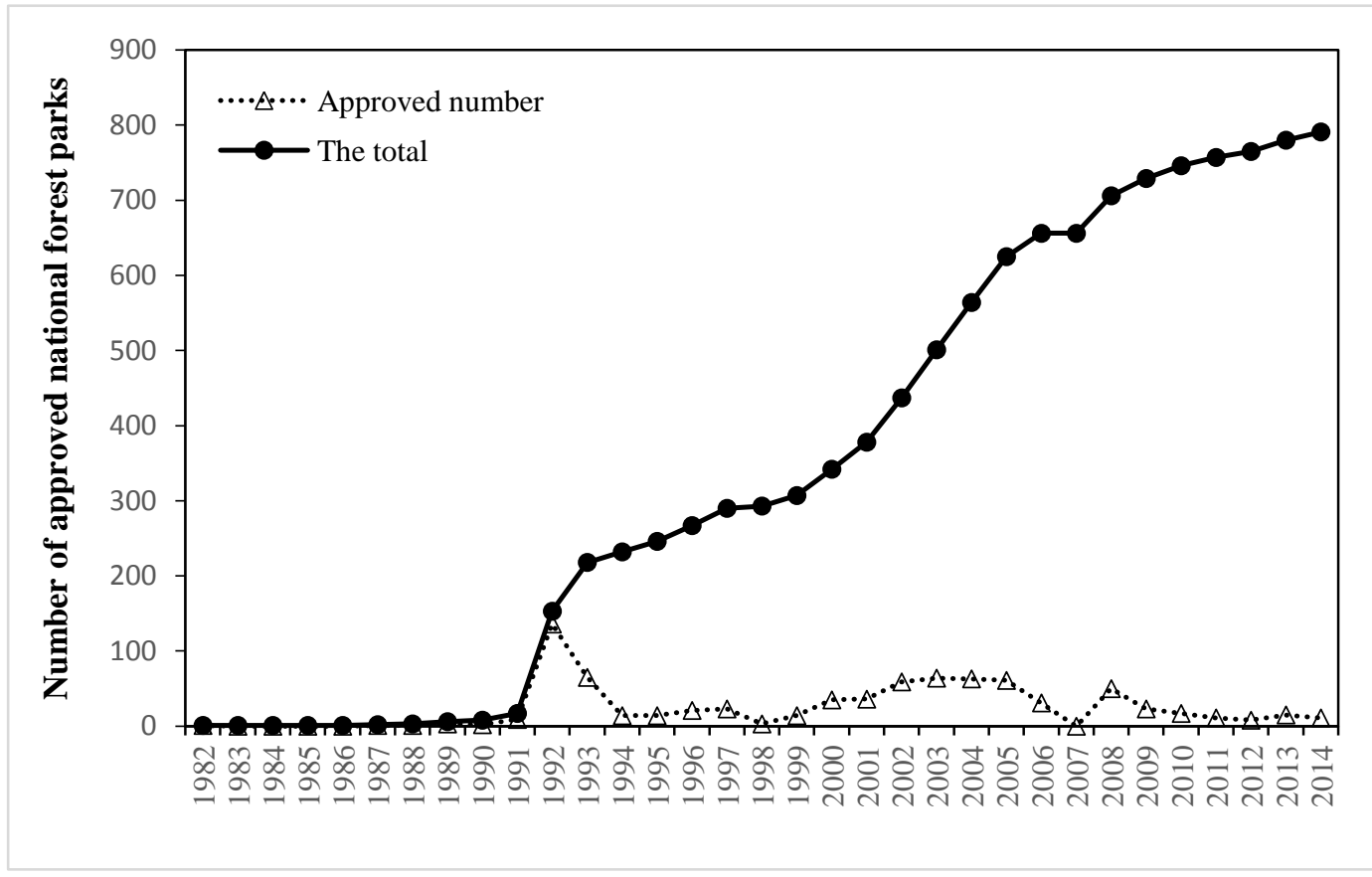

Fig. 1. Development of national forest parks in China from 1982-2014

Source: CSFA (2015).

Note: NCCPC refers to the National Congress of Communist Party of China. 


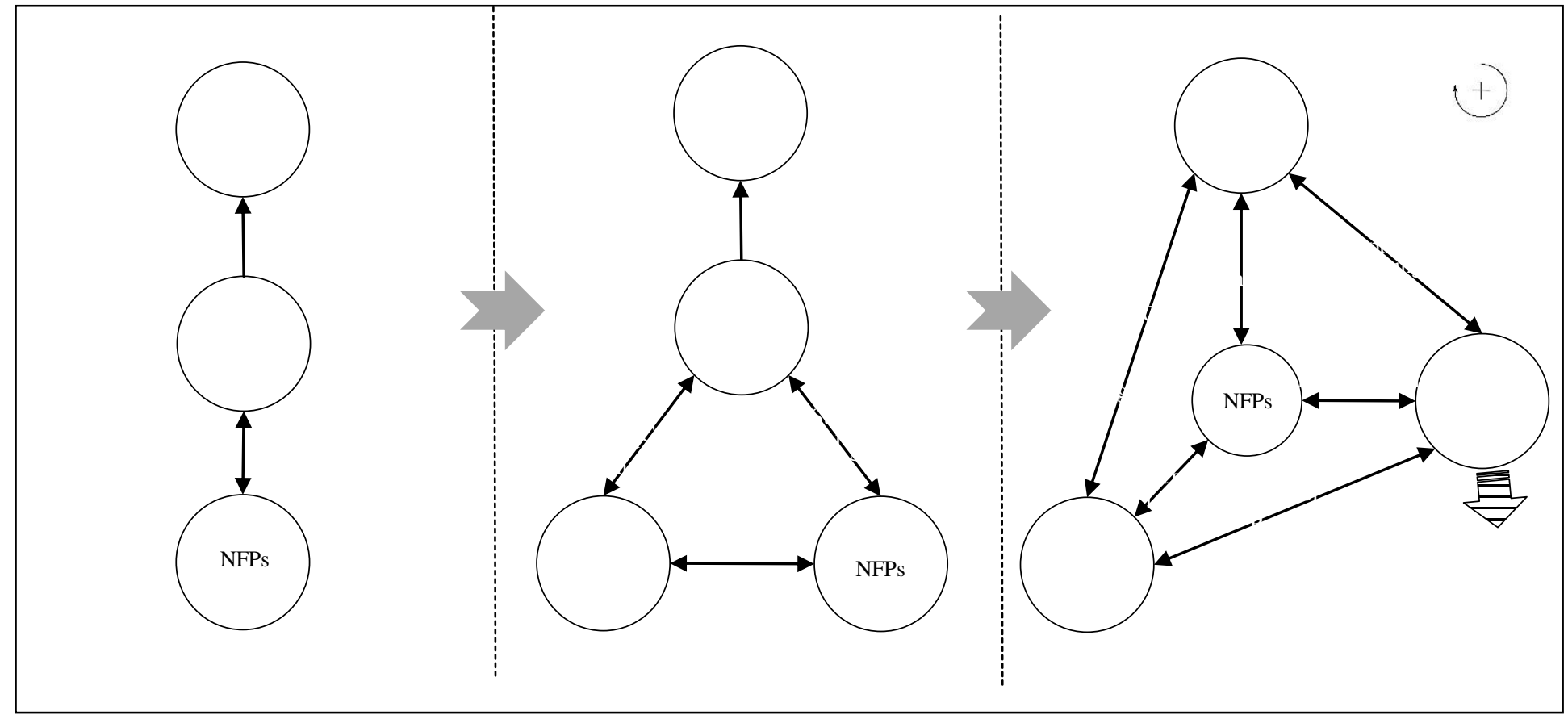

Fig. 2. Conceptual triad reflecting shift in the state, capital and society in NFPs from 1982 to 2014. 


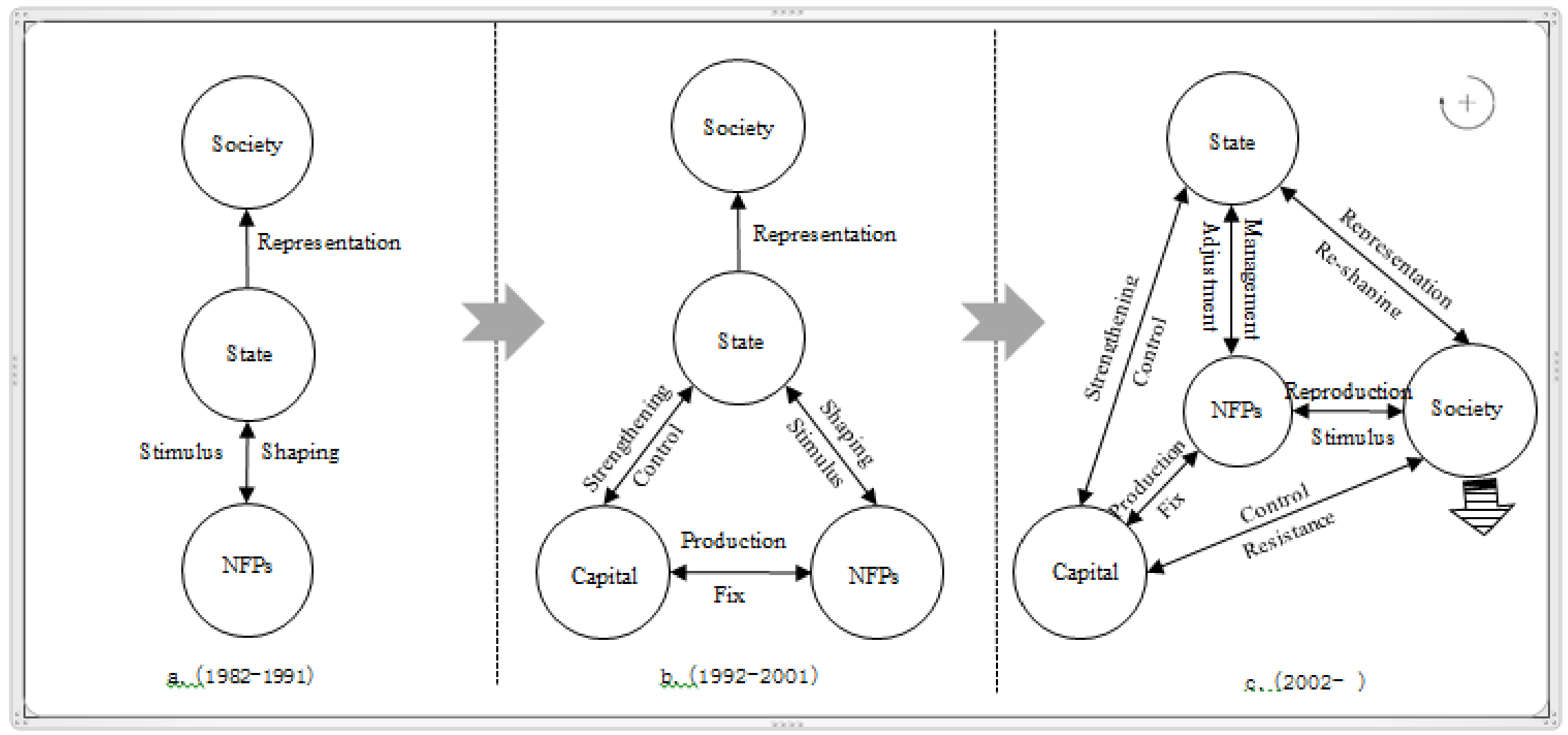

Fig. 2. Conceptual triad reflecting shift in the state capital and society in NFPs from 1982 to 2014 


\section{Table 1}

The classification system for national parks in China

\begin{tabular}{l|l|l}
\hline Type & Number & Administered by \\
\hline National Forest Park & 791 & State Forestry Administration \\
National Nature Reserve & 407 & State Forestry Administration \\
National Geopark & 240 & Ministry of Land Resources \\
National Wetland Park & 298 & State Forestry Administration \\
National Mining Park & 72 & Ministry of Land Resources \\
National Marine Park & 28 & State Oceanic Administration \\
National Historic and Interest Area & 225 & Ministry of Housing \& Urban-Rural Development \\
National Water Reserve Park & 658 & Ministry of water Resources \\
Total & $2708 *$ & \\
\hline
\end{tabular}

*Data is available from the administration websites until the end of 2014 
Table 2

A timeline of related forestry or tourism policy from CPC in China

\begin{tabular}{|c|c|c|c|}
\hline Year & Document name & Information source & Key words for economy, forest park and tourism \\
\hline 1978 & $3^{\text {rd }}$ plenary session of the $11^{\text {th }}$ CCCPC & СCCPC & The key points of the party should be shifted to the socialism modernization building. \\
\hline 1980 & $\begin{array}{l}\text { Instructions about developing } \\
\text { afforestation }\end{array}$ & CCCPC \& TSC & $\begin{array}{l}\text { Forestry is a very weak sector in national economy, facing ecological and economic crisis. The } \\
\text { party should depend on forestry and make diversification economy for forestry production. }\end{array}$ \\
\hline 1981 & $\begin{array}{l}\text { Several decisions on forest conservation } \\
\text { and forestry development }\end{array}$ & CCCPC & $\begin{array}{l}\text { Forestry is an important part of national economy. Forest preservation and forestry development is } \\
\text { an urgent strategy. }\end{array}$ \\
\hline 1981 & $\begin{array}{l}\text { Notice on agreement and forwarding } \\
\text { with the working report to strengthen } \\
\text { scenic and historic conservation }\end{array}$ & TSC & $\begin{array}{l}\text { Conservation and management of scenic and historic attractions could richen the cultural life for the } \\
\text { people, promote the development of tourism cause, and service four modernizations. }\end{array}$ \\
\hline 1982 & Ceremony report of $12^{\text {th }} \mathrm{NCCPC}$ & $\mathrm{CCCPC}$ & $\begin{array}{l}\text { The total task for CPC is to gradually realize the modernization of agriculture, military, science and } \\
\text { technology and build the country into a highly civilized and democratic socialist state. }\end{array}$ \\
\hline 1987 & Ceremony report of $13^{\text {th }}$ NCCPC & $\mathrm{CCCPC}$ & $\begin{array}{l}\text { The party clearly put forward the basic path for socialism at a primary level, which is 'one central } \\
\text { task, two basic points'. }\end{array}$ \\
\hline 1992 & Ceremony report of $14^{\text {th }}$ NCCPC & CCCPC & $\begin{array}{l}\text { The party should develop the socialist market economy, give priority to develop the productivity } \\
\text { and focus on the economic building to promote the social all-way progress. }\end{array}$ \\
\hline 1992 & $\begin{array}{l}\text { Decisions on developing the third } \\
\text { industry }\end{array}$ & CCCPC \& TSC & $\begin{array}{l}\text { Tourism industry is considered as one of the third industries with low investment, fast efficiency, } \\
\text { good profits, large employment and firm connection with the peoples' lives. }\end{array}$ \\
\hline 1995 & $5^{\text {th }}$ plenary session of the $14^{\text {th }}$ CCCPC & CCCPC & Tourism industry is ranked number one in emerging industries, which are also first put forward. \\
\hline 1997 & Ceremony report of $15^{\text {th }} \mathrm{NCCPC}$ & CCCPC & The sustainable development strategy is also first proposed by the CPC. \\
\hline 2001 & Notice on accelerating the development & TSC & The party should promote the tourism industry as a new growth point in national economy. \\
\hline
\end{tabular}


of tourism industry

2002

Decisions on accelerating forestry

development of tourism industry
The party must give top priority to sustainable development, help the whole nation see the importance of environmental protection and do a good job of ecological conservation and improvement.

Forestry is an important public service and a preliminary industry. We should develop new emerging products and industries (including ecotourism), and raise growth points for forestry economy.

The party must promote the ecological cultivation by basically forming an energy and resource efficient and environmentally friendly structure of industries, pattern of growth and mode of consumption.

Tourism industry should be brought up to the strategic keystone industry and the modern service industry satisfied by the people.

The party must give high priority to making ecological civilization and incorporate it into all aspects and the whole process of advancing economic, political, cultural, and social progress.

The party should speed-up the building of ecological civilization system and have a trail on the building of national park system.

Tourism industry is an important part of modern service industries, which plays a dramatic role in economic growth, environmental improvement, the well-being of people and the practice of core socialist values.

*Data is available from http://cpc.people.com.cn. 
Table 3

Key national forest pilot parks listed

\begin{tabular}{lllll}
\hline Name & $\begin{array}{l}\text { Year established } \\
\text { for FP }\end{array}$ & $\begin{array}{l}\text { Year established } \\
\text { for NFP }\end{array}$ & Province & Distinct Features \\
\hline Zhangjiajie & - & 1982 & Hunan & Geological landscape \\
Qiaodaohu & 1986 & 1990 & Zhejiang & Water landscape \\
Tiantong & 1982 & 1997 & Zhejiang & Forest and Buddhism landscape \\
Shatoujiao & - & 1989 & Guangdong & Seaside evergreen broad-leaf \\
& & 1993 & Guandong & Hot spring landscape \\
Liuxihe & 1983 & 1992 & Shaanxi & Canyon forest landscape \\
Louguantai & 1982 & 1992 & Shandong & Cultural landscape \\
Taishan & 1985 & 1992 & Shandong & Seaside forest landscape \\
Weihai & 1985 & 1992 & Anhui & Cultural landscape \\
Langyashan & 1985 & 1988 & Henai & Temple landscape \\
Songshan & 1986 & & & \\
\hline
\end{tabular}

*Data is available from China Forest Yearbook (1982-1994). 